\title{
PBR \\ Effect of non-thermal atmospheric pressure plasma on MDA-MB-231 breast cancer cells
}

\author{
Ramin Mehrabifard ${ }^{*}$, Hassan Mehdian ${ }^{1}$, Mahdi Bakhshzadmahmoudi2 ${ }^{2}$ \\ ${ }^{1}$ Department of Physics and Institute for Plasma Research, Kharazmi University, Mofatteh avenue Tehran, Iran \\ ${ }^{2}$ Nuclear Science and Technology Research Institute (NSTR), Plasma and Nuclear Fusion school, A,E,O, I, Tehran, Iran
}

\begin{tabular}{l}
\hline A R T I C L E I N F 0 \\
\hline *Corresponding author: \\
std r.mehrabifard@khu.ac.ir \\
\hline Article history: \\
Received: May 8, 2017 \\
Accepted: Jul 28, 2017 \\
\hline Keywords: \\
Non-thermal plasma \\
cancer cells \\
cell viability \\
MTT assay \\
MDA-MB-231 \\
\hline
\end{tabular}

\begin{abstract}
A B S T RACT
Cold atmospheric plasma (CAP) has received great attention due to its noteworthy ability, and has also been widely studied over few decades in physics, biology and medicine. The purpose of this study is to evaluate the cold atmospheric pressure plasma effects on the proliferation of breast cancer cells. MDAMB-231 was used for this experiment. MDA-MB-231 cells were cultured in 24-well plate and treated with non-thermal plasma. The viability of the cancer cells was determined by MTT assay. Different input power was applied in this experience $(20-35 \mathrm{~W})$, and treatment time was between $5 \mathrm{~s}$ and $25 \mathrm{~s}$. For reducing thermal damage, gas temperature was less than $37^{\circ} \mathrm{C}$. The Viability of breast cancer cells was significantly decreased after plasma treatment. The results showed that viability was decreased with an increment of plasma power and plasma exposure time. These results suggest that non-thermal atmospheric pressure plasma could strongly have cytotoxicity effect on cancerous breast cell.
\end{abstract}

Citation: Pharm Biomed Res 2017;3(3):12-16.

\section{Introduction}

Cold atmospheric pressure plasma involves partially ionized gas at low temperature in addition reactive species, electrons, positive and negative ions, excited molecules, UV photon and transient electric field (1). In last decades, cold atmospheric plasma (CAP) has been widely used in various fields. Plasma treatment has been used for materials processing in order to impart desired surface characteristics on paper, plastics, semiconductors, textiles (2-5), agriculture (6) and biomedical application such as bacterial inactivation $(7,8)$, dental whitening $(9)$, wound healing $(10)$, cancer cell treatment $(11,12)$, viral destruction (13). The temperature of all species in cold plasma is close to room temperature, allowing its application to living tissue temperature (14). Feasibly the most fascinating application in biology is the possible paradigm shift in cancer therapy. It has been shown repeatedly in literature that cold atmospheric plasma, when applied to cancer cell, induces the apoptotic pathway $(15,16)$. Different cancerous cell lines were investigated in the last decade, melanoma (17), C6 Glioma (1), lung carcinoma cells (18), etc.

In this study, we considered triple negative MDA-MB231 breast cancer cell and investigated the effects of cold atmospheric pressure plasma with different input power (20-35W) and different exposure time (5-25 second).

\section{Materials and Method}

\section{Plasma device}

Schematic diagram of plasma setup is shown in (figure 1). The Central electrode is connected to RF (Radio Frequency) signal with frequency $13.56 \mathrm{MHz}$, via an impedance-matching network. The central electrode is a steel wire of $1 \mathrm{~mm}$ diameter and grounded cylindrical electrode is steel with an inner diameter of $5 \mathrm{~mm}$, between two electrodes there is a glass as dielectric covered with Teflon strip. With an atmospheric pressure argon flow rate of 400-650 (10-14 mbar l/s), stable plasma was struck as shown in (figure 2). The gas temperature at tip of plasma was measured using a (JUMO iTRON 04) at the position of sample. As shown in (Figure 3) gas temperature at different RF power in the sample point was below $37{ }^{\circ} \mathrm{C}$ for all cell experiments reported here. For our experiment the input RF power was low and gas flow rate was sufficiently high, both helpful in cooling down the gas effluent.

\section{Cell culture}

Experiments were conducted with human breast cancer cells MDA-MB-231 (Pastor Institute, Tehran, Iran). The cells were cultured in RPMI (Bioidea, Iran) and $1 \%$ penicillin and streptomycin (Bioidea, Iran) supplemented with 10\% fetal bovine serum (Gibco, England). Cultures were maintained at $37{ }^{\circ} \mathrm{C}$ in humidified incubator (Binder incubator) containing $5 \% \mathrm{CO}_{2}$. 
In order to evaluate the growth of the cells, invert microscope (Carl Zeiss invert microscope) was used to observe. The cells $\left(10^{5}\right.$ cells per-well), plated in 24 wellplates. After $24 \mathrm{~h}$, cancer cells were exposed to the nonthermal plasma with different power of $\mathrm{RF}$ generator and different exposure time 5, 10, 15, 20 and $25 \mathrm{~s}$.

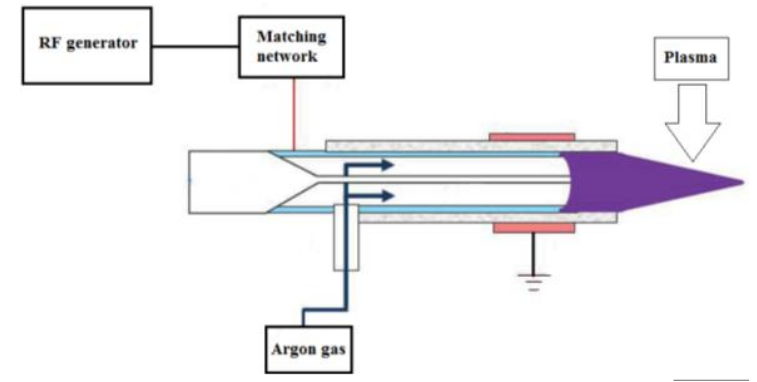

Figure 1 Schematic diagram of RF plasma

\section{MTT assay}

The viability of the MDA-MB-231 cells was determined using MTT assay which is a colorimetric assay for assessing activity of mitochondria and cellular dehydrogenate enzymes. MTT $=3-(4,5-$ dimethylthylthiazol-2-yl)-2,5-diphenyltetrazolium bromide is a yellow tetrazolium salt, which is transformed into purple Formozan because of mitochondria dehydrogenase in the living cells and causes color changes in the environment.

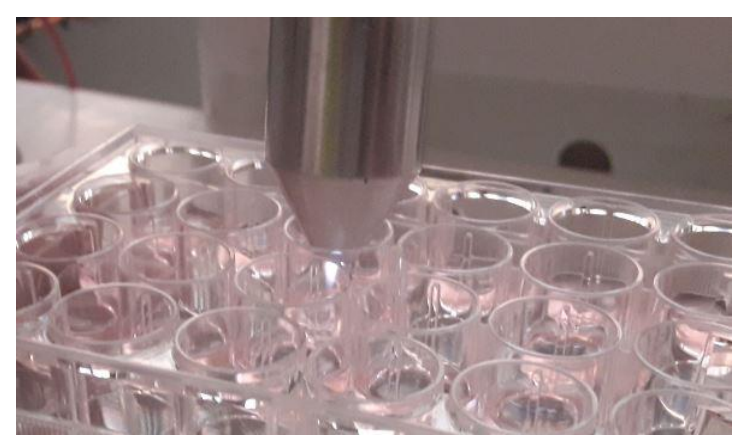

Figure 2 Cold atmospheric plasma treatment on MDAMB-231 cancer cells.

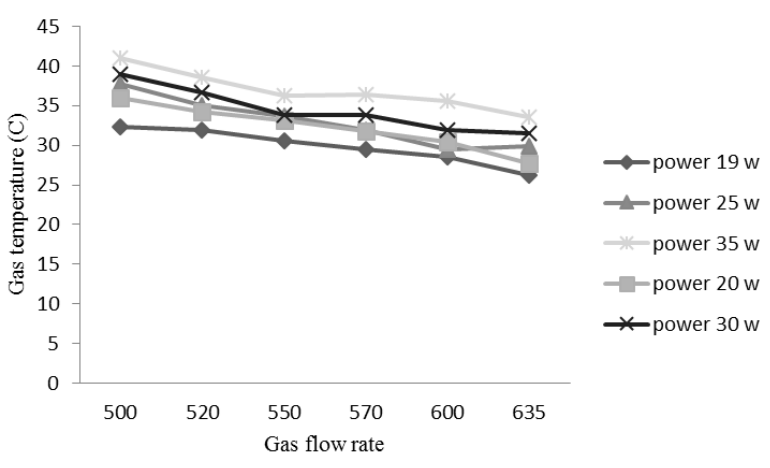

Figure 3 Gas flow rate dependence of gas temperature at sample point at different input RF power.
After $24 \mathrm{~h}$ incubation at $37{ }^{\circ} \mathrm{C}(19)$, MTT solution was added into each well and the plates were then incubated for 3 to 4 hours at $37^{\circ}$ C. After incubation, the solution was removed and $1 \mathrm{ml}$ DMSO (Dimethyl sulfoxide) was added to cells in order to dissolve crystals. The absorption was read by photo spectrometer at wavelength of $570 \mathrm{~nm}$. The experiment was repeated two times, and two samples were placed at each repetition. Non-thermal atmospheric pressure plasma is shown in (figure 2). Cells were plated in the 24-well plate at density of $10^{5}$ cells per well, then treated with plasma in $(5,10,15,20,25$, and 30s) and power of RF generator was at 20,25, 30 and 35 Watt. The viability of the MDA-MB-231 cells is examined by MTT assay. Cell viability can obtain with equation 1 :

percent of cell viability $(\%)=\frac{\text { treated sample absoption }}{\text { control sample absorption }} \times 100$ (1)

\section{Results}

The input power of $20 \mathrm{w}$ has been applied for the cancer cells treatment, exposure time was 5-25 seconds. In this test, the survival reduction has been observed as $\quad 6.3 \pm 0.05 \%, \quad 24.4 \pm 0.14 \%$, $31.7 \pm 0.15 \%, 40.5 \pm 0.10 \%$ and $58.5 \pm 0.07 \%$ for 5 , $10,15,20,25 \mathrm{~s}$, respectively. In order to further investigation, input power 25, 30 and 35 were tested. The result of MTT assay for 25-35 $w$ input power and exposure time of 5-25s, shown in (table 1).

Table 1 survival reduction for (25-35w) input power

\begin{tabular}{c|ccccc}
$\mathbf{P ( W )}$ & $\mathbf{5 S}$ & $\mathbf{1 0 S}$ & $\mathbf{1 5 S}$ & $\mathbf{2 0 S}$ & $\mathbf{2 5 S}$ \\
\hline \multirow{3}{*}{$\mathbf{2 5}$} & 13.82 & 31.16 & 41.82 & 47.8 & 63.97 \\
& \pm 0.07 & \pm 0.06 & \pm 0.16 & \pm 0.08 & \pm 0.12 \\
& $\%$ & $\%$ & $\%$ & $\%$ & $\%$ \\
$\mathbf{3 0}$ & 19.67 & 34.24 & 44.52 & 52.56 & 68.25 \\
& \pm 0.0 & \pm 0.17 & \pm 0.07 & \pm 0.01 & \pm 0.02 \\
& $\%$ & $\%$ & $\%$ & $\%$ & $\%$ \\
$\mathbf{3 5}$ & 29.81 & 46.78 & 54.96 & $67.87 \pm$ & 83.2 \\
& \pm 0.07 & \pm 0.02 & \pm 0.02 & 0.02 & \pm 0.03 \\
& $\%$ & $\%$ & $\%$ & $\%$ & $\%$
\end{tabular}

The highest cell death was at the highest treatment time of plasma exposure and highest input power $(25 \mathrm{~s}, 35 \mathrm{w})$. At the equal exposure time, increasing input power reduced cell survival and for each power, increasing exposure time decreased cell survival. The morphologic alternations of cells have been observed for control, 10, 15 and $20 \mathrm{~s}$ exposure time (Figure 4). The result of the input power 20-35 has been shown in (Figure 5-a, b, c, d). The obtained results indicated cold atmospheric plasma $(10,15$, $20 \mathrm{~s}$ ) induced cytoplasmic blebbing and cell 

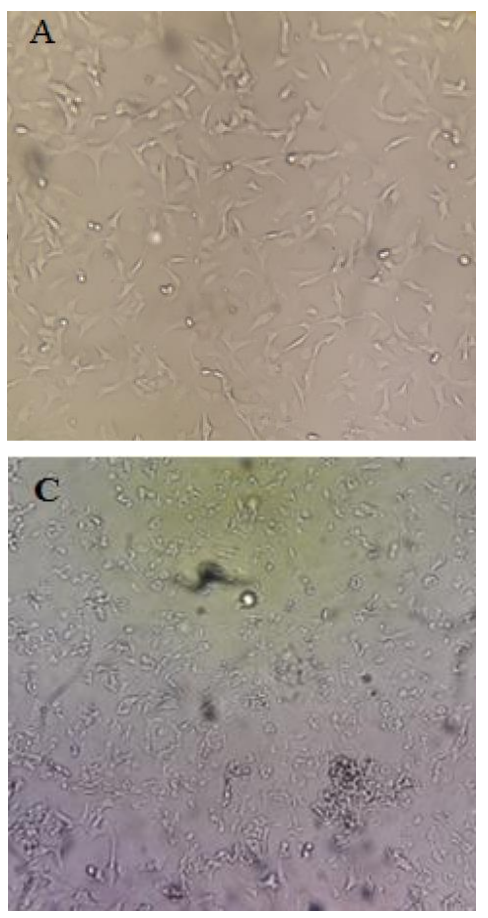

Figure 4 MDA-MB-231 cancer cell (A) control (B) 10 s exposure time (C) 15 s exposure time (D) $20 \mathrm{~s}$ exposure time treatment.
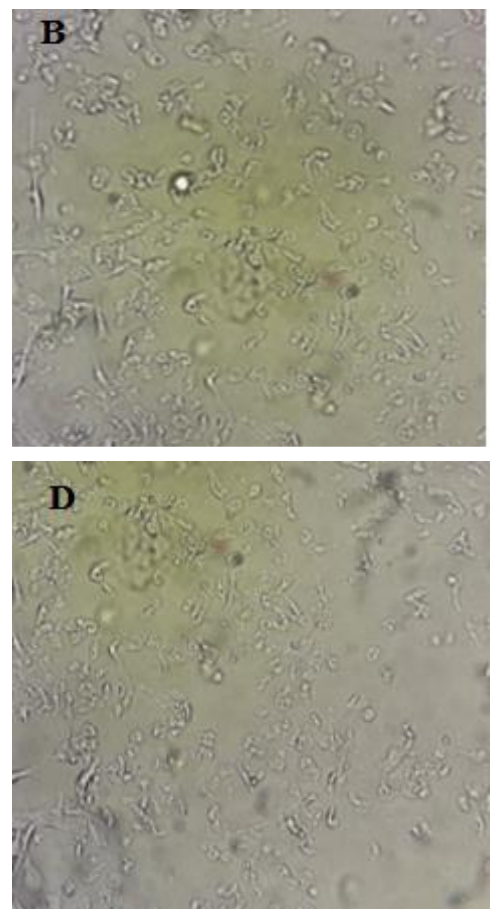
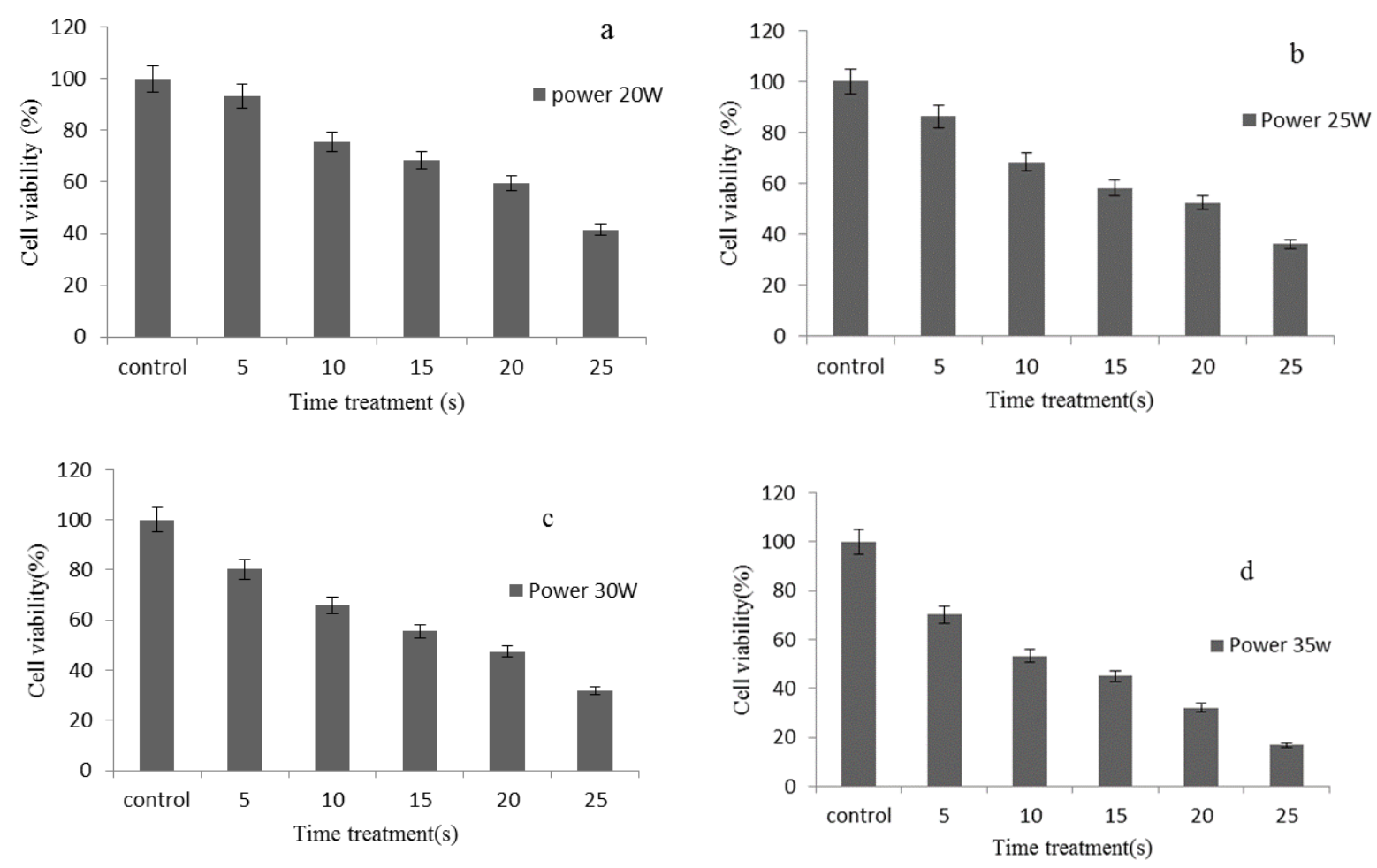

Figure 5 MDA-MB-231 breast cancer cells viability for 20,25,30,35 input powers. 
shrinkage so that these morphological alterations increased with the increment of exposure time. In order to comparison evaluate between times and input power, general trend has been shown in (figure 6) that indicate the effects of exposure time and input power on the survival of the cancerous cells. According to the MTT assay and morphological observation of cancer cells, with increasing input power and exposure time the viability of the cell will decrease.

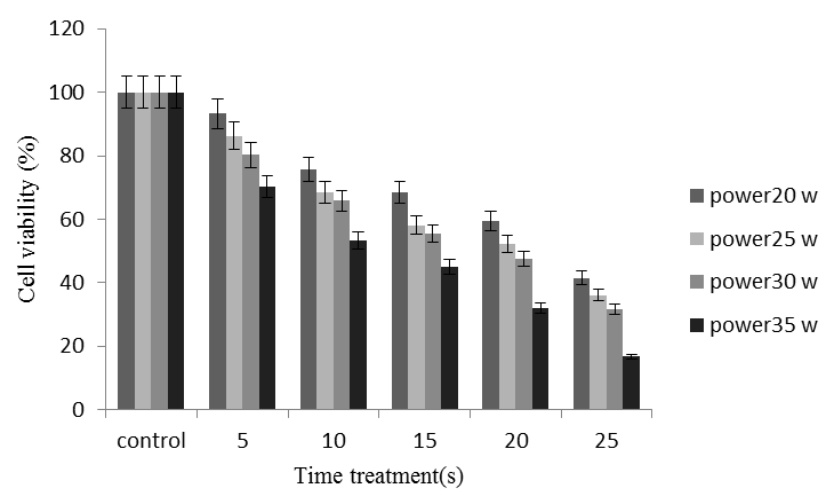

Figure 6 Cell viability in different power and different exposure time

\section{Discussions}

The cold atmospheric pressure plasma treatment on cells can lead to a raised level of free radical, which has an impact on cellular activity and elucidates the decrease of cell viability. In the initial period of using plasma in medicine, a huge number of paper have been published to characterize several effects of CAP on healthy and cancer cells in vitro. Despite the use of different plasma sources, working gases, cell types, experimental setups, etc. some general plasma effects on biology have been described many times (20-24). Based on this fundamental knowledge on general reaction of living cells and tissue to plasma treatment, more basic studies have been done to understand and elucidate mechanisms of these biological effect using highly intricate cell biological and molecular biological techniques.

The biological effects of CAP are based on two major fundamental principles as:

1. Biological plasma effects are significantly caused by plasma impelled changes of the liquid environment of cells.

2. Reactive nitrogen and oxygen species (RNS, ROS) that are generated in or transferred into liquid phases play an important role in plasma-induced biological responses.

Other plasma ingredients like UV radiation or electrical current/electrical fields are considered to play supplementary roles in the active plasma. However, UV part of cold plasma is estimated to have low or no direct biological effects because typically low doses are emitted by plasma devices chosen for medical use. But its supporting role in reactive species generation has to be taken into consideration. Electrical fields or current, respectively, reaching living tissue depends strongly on the type of discharge and therefore will cause varying direct biological effects. Much more research is needed in this field to finally construe the role of plasma compound for its possible direct part in biological and medical related plasma action but also for its role in the generation or support of the action of other plasma ingredients, above all of reactive species (25). Although these RS generated in the gas phase plasma cannot directly react with the cells due to the protection rendered by the nutrient solution, they can initiate various chemical reactions at the gas-liquid interface and then form large amounts of primary and secondary $\mathrm{RS}$ such as $\left(\mathrm{NO}_{2} \bullet, \mathrm{NO} \bullet, \mathrm{NO}_{2}^{-}\right.$and $\left.\mathrm{NO}_{3}^{-}\right)$in the liquid phase. Nitrogen oxides generated from the argon plasma (26) dissolve in the liquid forming nitrites and nitrates in the liquid by the reaction (aq.) means an aqueous species $(27,28)$

$$
\begin{aligned}
& \mathrm{N}_{2} \mathrm{O}_{3}(a q)+\mathrm{H}_{2} \mathrm{O} \rightarrow \mathrm{HNO}_{2}(a q)+\mathrm{HNO}_{2}(a q) \\
& \mathrm{NO}_{(a q)}+\mathrm{NO}_{2(a q)} \rightarrow \mathrm{HNO}_{2(a q)}+\mathrm{HNO}_{2(a q)} \\
& \mathrm{NO}_{(a q)}+\mathrm{HO}_{2(a q)} \rightarrow \mathrm{HNO}_{2(a q)}
\end{aligned}
$$

Ozone is generated in plasma- treated solution as follows:

$\mathrm{O}_{2}+\mathrm{O} \bullet{ }_{(a q)} \rightarrow \mathrm{O}_{3}$

$\mathrm{O}_{3(\text { gas })} \rightarrow \mathrm{O}_{3(\mathrm{aq})}$

$\mathrm{OH} \bullet$ And $\mathrm{H}_{2} \mathrm{O}_{2}$ are formed by excitation and /or ionization of water molecules by energetic species in plasma $(1,28-30)$

$$
\begin{aligned}
& \mathrm{H}_{2} \mathrm{O}_{(a q)}+e \rightarrow \mathrm{H} \bullet{ }_{(a q)}+\mathrm{OH} \bullet_{(a q)}+e \\
& \mathrm{H}_{2} \mathrm{O}_{(a q)}+e \rightarrow \mathrm{H}_{2} \mathrm{O}^{+}+2 e \\
& \mathrm{H}_{2} \mathrm{O}_{(a q)}^{2}+\mathrm{H}_{2} \mathrm{O}_{(a q)} \rightarrow \mathrm{OH} \bullet_{(a q)}+\mathrm{H}_{3} \mathrm{O}_{(a q)}^{+} \\
& 2 \mathrm{H}_{2} \mathrm{O}_{2(a q)}+e \rightarrow \mathrm{H}_{2}+\mathrm{H}_{2} \mathrm{O}_{2(a q)}+e \\
& \mathrm{OH} \bullet_{(a q)}+\mathrm{OH} \bullet_{(a q)} \rightarrow \mathrm{H}_{2} \mathrm{O}_{2(a q)}
\end{aligned}
$$

It is difficult to discern the concentration of shortlived reactive species in the plasma-treated solution due to the short half-life and high reactivity. However, the presence of the long-lived reactive 
species in the aqueous phase can provide indirect proof of the existence of short-lived reactive species according to the aforementioned reactions. As shown in chemical reactions, these ROS/RNS in the liquid produced by plasma are important intermediates in biological reactions, but it is not clear what the exact roles these ROS/RNS play in cell apoptosis. The result suggests that cell inactivation and damage are depended on to increase RS concentration in the medium.

\section{Conclusion}

RF atmospheric pressure plasma was used for treatment of human breast cancer cells MDA-MB231.By controlling the RF input power and the gas flow rate argon gas, the gas temperature was found below $37^{\circ} \mathrm{C}$ and plasma effects were predominantly non-thermal. Regarding to the result, breast cancer cells viability directly depends on exposure time of plasma and input power to the system. Mechanism of cell death is not clear yet but ROS and RNS generated in the plasma and medium have important role in cell survival attenuating.

\section{Acknowledgement}

The authors would like to thank Cell and Molecular biology faculty member at kharazmi University for use of their facilities, Cell culture and analytical device. This work was supported by physics and institute for plasma research at Kharazmi University.

\section{Conflict of interest}

The authors report no conflicts of interest.

\section{References}

1. Wang Y, Cheng C, Gao P, Li S, Shen J, Lan Y, et al. Cold atmospheric-pressure air plasma treatment of C6 glioma cells: effects of reactive oxygen species in the medium produced by the plasma on cell death. Plasma Sci Technol 2017;19:25503.

2. Noeske M, Degenhardt J, Strudthoff S, Lommatzsch U. Plasma jet treatment of five polymers at atmospheric pressure: surface modifications and the relevance for adhesion. Int $\mathbf{J}$ Adhes Adhes 2004;24:171-7.

3. Yang S, Yin H. Two atmospheric-pressure plasma sources for polymer surface modification. Plasma Chem Plasma Process 2007;27:23-33.

4. Temmerman E, Akishev Y, Trushkin N, Leys C, Verschuren J. Surface modification with a remote atmospheric pressure plasma: $\mathrm{dc}$ glow discharge and surface streamer regime. J Phys D Appl Phys 2005;38:505.

5. Kim J-H, Liu G, Kim SH. Deposition of stable hydrophobic coatings with in-line $\mathrm{CH} 4$ atmospheric RF plasma. J Mater Chem 2006;16:977-81.

6. Puligundla P, Kim J-W, Mok C. Effect of corona discharge plasma jet treatment on decontamination and sprouting of rapeseed (Brassica napus L.) seeds. Food Control 2017;71:376-82

7. Laroussi M. Low temperature plasma-based sterilization: overview and state-of-the-art. Plasma Process Polym 2005;2:391-400.
8. Deng X, Shi J, Kong MG. Physical mechanisms of inactivation of Bacillus subtilis spores using cold atmospheric plasmas. IEEE Trans Plasma Sci 2006;34:1310-6.

9. Lee HW, Kim GJ, Kim JM, Park JK, Lee JK, Kim GC. Tooth bleaching with nonthermal atmospheric pressure plasma. J Endod 2009;35:587-91.

10. Fridman G, Friedman G, Gutsol A, Shekhter AB, Vasilets VN, Fridman A. Applied plasma medicine. Plasma Process Polym 2008;5:503-33.

11. Fridman G, Shereshevsky A, Jost MM, Brooks AD, Fridman A, Gutsol A, et al. Floating electrode dielectric barrier discharge plasma in air promoting apoptotic behavior in melanoma skin cancer cell lines. Plasma Chem Plasma Process 2007;27:163-76.

12. Kim GC, Kim GJ, Park SR, Jeon SM, Seo HJ, Iza F, et al. Air plasma coupled with antibody-conjugated nanoparticles: a new weapon against cancer. J Phys D Appl Phys 2008;42:32005.

13. Shi X-M, Zhang G-J, Wu X-L, Peng Z-Y, Zhang Z-H, Shao X-J, et al. Effect of low-temperature plasma on deactivation of hepatitis $B$ virus. IEEE Trans Plasma Sci 2012;40:2711-6.

14. Keidar M. Plasma for cancer treatment. Plasma Sources Sci Technol 2015;24:33001.

15. Fridman A, Friedman G. Plasma Medicine. Hoboken. NJ: Wiley; 2013.

16. Laroussi M, Kong MG, Morfill G, Stolz W. Plasma medicine. Plasma Med by M Laroussi, MG Kong, G Morfill, W Stolz, Cambridge, UK Cambridge Univ Press 2012. 2012;

17. Ishaq M, Bazaka K, Ostrikov K. Intracellular effects of atmosphericpressure plasmas on melanoma cancer cells. Phys Plasmas 2015;22:122003.

18. Kim JY, Ballato J, Foy P, Hawkins T, Wei Y, Li J, et al. Apoptosis of lung carcinoma cells induced by a flexible optical fiber-based cold microplasma. Biosens Bioelectron 2011;28:333-8.

19. Chen Z, Lin L, Cheng X, Gjika E, Keidar M. Effects of cold atmospheric plasma generated in deionized water in cell cancer therapy. Plasma Process Polym 2016;13:1151-6.

20. Fridman A. Plasma chemistry. Cambridge university press; 2008.

21. Stoffels E, Sakiyama Y, Graves DB. Cold atmospheric plasma: charged species and their interactions with cells and tissues. IEEE Trans Plasma Sci 2008;36:1441-57.

22. Isbary G, Heinlin J, Shimizu T, Zimmermann JL, Morfill G, Schmidt $\mathrm{H}-\mathrm{U}$, et al. Successful and safe use of 2 min cold atmospheric argon plasma in chronic wounds: results of a randomized controlled trial. Br J Dermatol 2012;167:404-10.

23. Haertel B, von Woedtke T, Weltmann K-D, Lindequist U. Nonthermal atmospheric-pressure plasma possible application in wound healing. Biomol Ther (Seoul) 2014;22:477-90.

24. Dobrynin D, Fridman G, Friedman G, Fridman A. Physical and biological mechanisms of direct plasma interaction with living tissue. New J Phys 2009;11:115020.

25. Darny T, Robert E, Dozias S, Pouvesle J. Electric field measurements during plasma jet operation on/in biological samples and tissues. In: Plasma Sciences (ICOPS), 2015 IEEE International Conference on. 2015. p. 1.

26. Machala Z, Tarabova B, Hensel K, Spetlikova E, Sikurova L, Lukes P. Formation of ROS and RNS in Water Electro-Sprayed through Transient Spark Discharge in Air and their Bactericidal Effects. Plasma Process Polym 2013;10:649-59.

27. Tian W, Kushner MJ. Atmospheric pressure dielectric barrier discharges interacting with liquid covered tissue. J Phys D Appl Phys 2014;47:165201.

28. Liu ZC, Liu DX, Chen C, Li D, Yang AJ, Rong MZ, et al. Physicochemical processes in the indirect interaction between surface air plasma and deionized water. J Phys D Appl Phys 2015;48:495201.

29. Du CM, Sun YW, Zhuang XF. The Effects of Gas Composition on Active Species and Byproducts Formation in Gas--Water Gliding Arc Discharge. Plasma Chem Plasma Process 2008;28:523-33.

30. Van Gils CAJ, Hofmann S, Boekema B, Brandenburg R, Bruggeman PJ. Mechanisms of bacterial inactivation in the liquid phase induced by a remote RF cold atmospheric pressure plasma jet. J Phys D Appl Phys 2013;46:175203. 